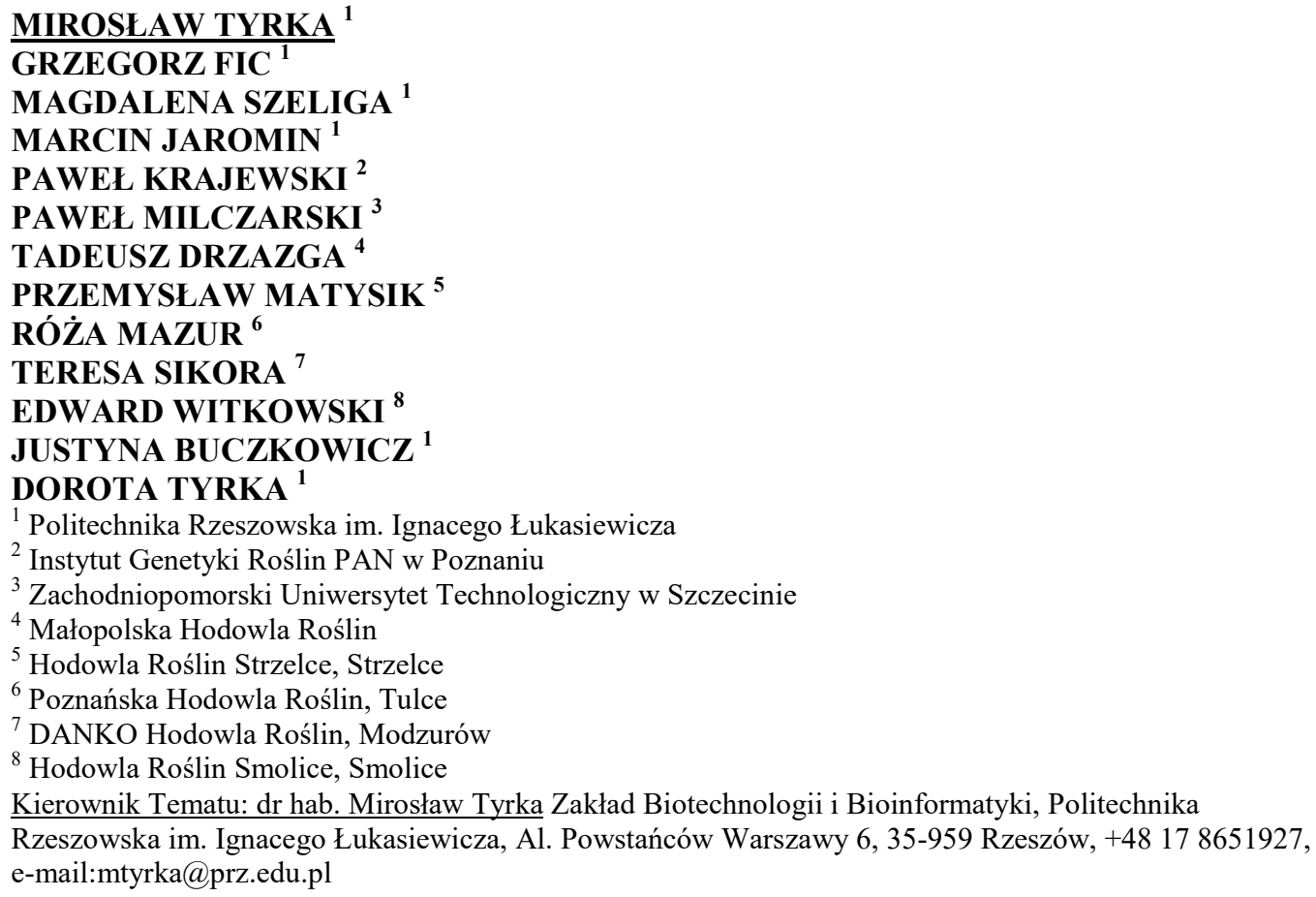

Prace zostały wykonane $w$ ramach badan podstawowych na rzecz postępu biologicznego w produkcji roślinnej na podstawie decyzji Ministra Rolnictwa i Rozwoju Wsi nr decyzji HOR.hn.802.12.2018, Zadanie 109.

\title{
Selekcja genomowa pszenicy ozimej
}

\section{Genomic selection of winter wheat}

Słowa kluczowe: genotypowanie przez sekwencjonowanie, pszenica zwyczajna, zmienność epigenetyczna

\section{CEL BADAŃ}

Celem badań było poszerzenie wiedzy na temat uwarunkowań genetycznych i epigenetycznych kształtujących zmiany w wysokości plonowania. Plon jest niezwykle złożoną cechą, a hipoteza badawcza zakłada, że część tej zmienności jest kształtowana 
przez zmiany epigenetyczne. Realizacja przewidzianego cyklu badań powoli na określenie udziału i roli tych zmian w kształtowaniu plonu.

Celem zadania jest:

1. wdrożenie metody genotypowania przez sekwencjonowanie (GBS) wrażliwej na metylację,

2. wykorzystanie metody GBS do oznaczenia zmienności genetycznej w grupie 200 genotypów pszenicy zwyczajnej scharakteryzowanych pod względem plonu,

3. ocena zmienności fenotypowej $\mathrm{w}$ doświadczeniu porównawczym $\mathrm{w}$ wybranych lokalizacjach.

\section{OPIS WYNIKÓW}

Pierwszy cel badawczy, tj. wdrożenie i optymizację metody GBS realizowano w etapach: a) wybór endonuleaz do fragmentacji DNA, b) wybór dodatkowego enzymu wrażliwego na zmiany metylacyjne $\mathrm{w}$ celu redukcji złożoności bibliotek, c) projektowanie adaptorów do konstrukcji bibliotek, d) konstrukcja i ocena ilościowa bibliotek, e) sekwencjonowanie bibliotek f) obróbka bioinformatyczna uzyskiwanych danych pozwalająca na ocenę pokrycia i powtarzalności wyników.

Dla 43 enzymów restrykcyjnych rozpoznających różne motywy 6-nuleotydowe określono liczbę fragmentów o wielkości w zakresie od 75 do 150 nukleotydów. Przewidziano \% fragmentów unikalnych i ich rozkład w genomie podzielonym na partycje o wielkości $300 \mathrm{kpz}$. W efekcie przeprowadzonych symulacji komputerowych stwierdzono, że liczba fragmentów o wielkości w zakresie $75-150 \mathrm{pz}$ generowana przez poszczególne enzymy wynosi średnio 147 tysięcy i w zależności od zastosowanego enzymu restrykcyjnego waha się w szerokim zakresie od 14 do 483 tys. fragmentów. Udział fragmentów unikalnych dla zestawu enzymów restrykcyjnych wynosił od 63,5\% do $92,5 \%$. Średnie pokrycie genomu przez uzyskiwane fragmenty wyniosło $73 \%$ i wahało się od $99,4 \%$ do $21,6 \%$. (tab. 1). Na podstawie danych o liczbie fragmentów unikalnych i pokryciu do wstępnych testów wybrano 3 enzymy restrykcyjne.

W drugim etapie symulacji przewidziano ilości i rozkład fragmentów po dodatkowym trawieniu redukcyjnym enzymem rozpoznającym motywy $4 \mathrm{pz}$. Na podstawie symulacji komputerowej wybrano 5 kombinacji enzymów (oznaczonych M1-M5) i zaprojektowano adaptory dla 12 losowych barkodów odpowiadających odmianom pszenicy ozimej wybranym losowo z listy odmian roślin uprawnych (KWS Ozon, Mewa, Muszelka, Natula, Nutka, Opcja, Ostka Strzelecka, Ostroga, Owacja, Pokusa, Sailor i Satyna).

W celu weryfikacji symulacji, zaadaptowano metodykę Poland i in. (2012) do wytypowanych kombinacji enzymów restrykcyjnych. Stosowano adaptory do pierwszego enzymu. Fragmenty o docelowej wielkości 75-150 nukleotydów, po uwzględnieniu ligowanych adaptorów, wycinano $\mathrm{z}$ żelu, oczyszczano i charakteryzowano na fluorymetrze. Próbki łączono w ilościach równomolowych i sekwencjonowano na aparacie Miseq zgodnie z instrukcją. 
Charakterystyka polimorfizmu w bibliotekach M1-5. W analizie rozkładu podano liczbę genotypów u których wykryto zmienność w tym samym locus

\begin{tabular}{|c|c|c|c|c|c|c|c|c|c|c|}
\hline Biblioteka & \multicolumn{2}{|c|}{ M1 } & \multicolumn{2}{|c|}{ M2 } & \multicolumn{2}{|c|}{ M3 } & \multicolumn{2}{|c|}{ M4 } & \multicolumn{2}{|c|}{ M5 } \\
\hline Liczba wszystkich sekwencji & 89396 & & 97884 & & 3046 & & 406 & & 6106 & \\
\hline Liczba sekwencji unikalnych & & 55550 & & 56926 & & 977 & & 252 & & 2083 \\
\hline $\begin{array}{c}\text { Średnie pokrycie } \\
\text { Rozkład }\end{array}$ & 1,39 & 1,27 & 1,06 & 1,08 & 2,29 & 2,38 & 1,38 & 1,34 & 2,21 & 2,16 \\
\hline 12 & 2 & 0 & 0 & 0 & 5 & 3 & 0 & 0 & 3 & 3 \\
\hline 11 & 0 & 0 & 4 & 3 & 5 & 5 & 0 & 0 & 12 & 10 \\
\hline 10 & 3 & 0 & 0 & 0 & 16 & 15 & 0 & 0 & 30 & 13 \\
\hline 9 & 1 & 1 & 3 & 3 & 31 & 14 & 0 & 0 & 45 & 29 \\
\hline 8 & 13 & 1 & 3 & 2 & 41 & 15 & 0 & 0 & 66 & 29 \\
\hline 7 & 40 & 9 & 3 & 3 & 47 & 14 & 3 & 2 & 113 & 42 \\
\hline 6 & 147 & 21 & 13 & 11 & 75 & 28 & 2 & 1 & 179 & 52 \\
\hline 5 & 489 & 111 & 40 & 33 & 137 & 43 & 1 & 1 & 261 & 66 \\
\hline 4 & 1758 & 526 & 167 & 122 & 194 & 51 & 6 & 4 & 391 & 124 \\
\hline 3 & 5240 & 2249 & 627 & 434 & 392 & 102 & 28 & 13 & 650 & 150 \\
\hline 2 & 16316 & 8294 & 4325 & 2877 & 571 & 158 & 49 & 28 & 1065 & 278 \\
\hline 1 & 65387 & 44338 & 92699 & 53438 & 1532 & 529 & 317 & 203 & 3291 & 1287 \\
\hline
\end{tabular}

Uzyskiwane dane $\mathrm{z}$ sekwencjonowania przypisywano do poszczególnych próbek na podstawie adresów, następnie czyszczono z sekwencji o błędach przekraczających 1 nukleotyd na 1000. Oczyszczone dane posłużyły do wydzielenia dla każdej z bibliotek oddzielnie puli fragmentów unikalnych (unigenów). Wprowadzenie tego etapu do analizy miał na celu przyspieszenie docelowych obliczeń dla dużej liczby próbek. Najwyższa liczba sekwencji unikalnych była dla bibliotek M1 i M2. Sekwencje unikalne w bibliotekach M3-M5 stanowiły od 324 tysięcy do 575 tysięcy. Następnie wykonano dopasowanie unikalnych sekwencji do genomu referencyjnego pszenicy i uzyskano pliki (SAM, Sequence Alignment Map) zawierające informacje o pozycji fizycznej markera na chromosomach pszenicy. W kolejnym etapie w sekwencjach uzyskanych z poszczególnych bibliotek i genotypów identyfikowano mutacje punktowe (SNP). Dane o występowaniu SNP w poszczególnych badanych odmianach w bibliotekach M1-5 zebrano i przeanalizowano pod kątem zmienności (tab. 1). W bibliotekach M1 i M2 stwierdzono występowanie odpowiednio 89 tys. i 98 tys. fragmentów co przekracza możliwości rzetelnej oceny na aparacie Miseq. W przypadku bibliotek M3-M5 uzyskiwane liczby markerów były akceptowalne i pokrycie wystarczające do identyfikacji SNP można uzyskać na posiadanym aparacie. Analizując rozkład fragmentów w badanych odmianach do dalszych analiz na 200 genotypach wybrano kombinację M5.

W ramach realizacji drugiego etapu prac kombinację enzymów M5 wykorzystano do uzyskania i sekwencjonowania 3 bibliotek (po 67 genotypów każda). Uzyskane dane są w trakcie obróbki bioinformatycznej i będą wykorzystane do identyfikacji markerów epigenetycznych po skompletowaniu wyników oceny fenotypowej.

W ramach realizacji trzeciego celu badawczego założono doświadczenia w 5 lokalizacjach (Strzelce, Modzurów, Nagradowice, Smolice, Kobierzyce). Określono wysokość plonu ziarna o wilgotności $15 \%$ dla 200 genotypów badanych w 4 seriach w odniesieniu do wzorców w układzie bloków niekompletnych. We wszystkich seriach stwierdzono 
istotne efekty związane z genotypem badanych linii. Analiza wariancji z uwzględnieniem lat i miejscowości wskazuje na celowość uzupełnienia analiz o zmienne towarzyszące uwzględniające warunki pogodowe panujące w trakcie wegetacji.

\section{WNIOSKI}

W efekcie przeprowadzonych badań wdrożono skalowalną metodykę skanowania całego genomu pszenicy. Wydajność opracowanego systemu docelowo powinna pozwalać na uzyskiwanie do 6000 markerów na genotyp. Proponowany system ma wydajność pośrednią pomiędzy markerami DArT bazującymi na hybrydyzacji (około 1000 markerów) a systemem DArTseq (około 20000 markerów). Uzyskano dane o plonowaniu 200 linii pszenicy ozimej po uzupełnieniu o dane z doświadczenia założonego w 2018 roku będą wartościowe bez względu na rozwój technologii markerowych i mogą służyć obliczaniu efektów selekcyjnych oraz identyfikacji markerów epigenetycznych związanych z plonowaniem.

\section{LITERATURA}

Poland J. A, Brown P. J., Sorrells M. E., Jannink J.-L. 2012. Development of high-density genetic maps for barley and wheat using a novel two-enzyme genotyping-by-sequencing approach. PloS ONE 7 (2): e32253. 